\title{
AGRARIAN PRECURSORS OF THE MEXICAN REVOLU- TION: THE DEVELOPMENT OF AN IDEOLOGY
}

$\mathrm{D}$ URING the second half of the nineteenth century, when Mexico was beginning a slowly drawn-out process of industrialization and urbanization, the seemingly quiet countryside was experiencing agrarian unrest of proportions unprecedented in the nation's history. Trapped between increasing population on diminished ejidal and pueblo landholdings and ever-growing estates and demands of large property owners, Mexican campesinos in three states-eastern Morelos, southeastern Mexico, and northwestern Puebla- sought relief by means of insurrection. Because these agrarian uprisings during the last third of the nineteenth century were a prelude to similar and more famous occurrences during the fateful epoch 1910-1917, their causes, nature, and significance are essential for understanding an important aspect of the Mexican Revolution. ${ }^{1}$

Serious agrarian unrest in Mexico dates back to the early nineteenth century and the independence struggles led by Hidalgo and Morelos; but the first purely agrarian uprising of significance did not take place until 1849, when 1,000 poorly-armed campesinos raided haciendas and seized Rio Verde, a town near Querétaro. The notorious rapine and savagery of this episode set a pattern for the struggles that followed. Most significantly, the leader of these illiterate campesinos, Eleuterio Quiroz, set a precedent by demanding redistribution to the peones of the more populous lands of the bacendados. The campesinos, however, made no organized or sustained campaign; and they offered no ideological critique of society as a basis for justifying their grievances or making their demands for change. ${ }^{2}$ Agrarian tumult continued in this same sporadic and muted vein until the late 1860's, when it sharply increased and took on an entirely new dimension as a result of the appearance of a revolutionary doctrine.

\footnotetext{
${ }^{1}$ In recent years a number of works have been published describing the exploits of Mexican agrarian revolutionary leaders such as Emiliano Zapata, Francisco Villa and Pascual Orozco. Yet, while virtually all observers agree that agrarian grievances were inherited from the nineteenth century and more particularly from the Díaz regime, none of these studies which delve into the agrarian aspect of the Mexican Revolution have selectively examined the significance or possible influence of particular agrarian precursors of the conflagration that erupted in 1910.

2 For discussions of the Rio Verde uprising see Valentín Gama, "La Propiedad en México. La Reforma Agraria," Revista Mexicana de Ingenería y Arquitectura, (México D. F., 1931), Numbers 6, 8, 9, and 10; also, Jesús Silva Herzog, El Agrarismo Mexicano y La Reforma Agraria, (México D. F., 1959), 62-63.
} 
This first important turning point in the agrarian movement occurred in 1869 when Julio Chávez López, a campesino originally from Texcoco, led an insurrection near Chalco in the southeastern corner of the state of Mexico. The Chávez López uprising marked the departure from the irrational pillaging and rioting that had typified its predecessors. ${ }^{3}$ For the first time, agrarians expressed immediate goals which they derived from an ideological critique of the Mexican government.

The causes of the Chalco dispute were deeply rooted in the past. Long before the arrival of the Spanish in the sixteenth century, the province of Chalco was one of the principal centers of habitation in the central valley of Mexico. Its major town or cabecera, Chalco, on the basis of political importance and population, ranked third behind Tenochtitlan, the Aztec capital, and Texcoco, a principal ally of the Aztecs. After the Spanish intrusion, Texcoco declined rapidly and was soon replaced by Chalco as the second ranking Indian city in the valley. According to tribute statistics, Chalco retained both its size and political importance, relative to the other pre-Columbian settlements except Mexico City, throughout the colonial period. ${ }^{4}$

While Chalco retained its relative importance, it, like other settlements, was decimated by the epidemics of the sixteenth century. Depopulation was so rapid during the latter half of the century that the lands became unoccupied faster than they could be redistributed or absorbed by Spanish seizures. By 1600 much of the land in the Chalco area was abandoned; the indigenous population was simply too small to cultivate the vacant territory. Village agriculture came to be increasingly concentrated in the area contiguous to settlement. Corrupt town officials took advantage of this situation and either sold or rented the property to Spaniards. By the eighteenth century the Chalco area was characterized by Spanish-Creole-owned haciendas that dominated Indian society in the province. The largest, most powerful, and most enduring haciendas established near Chalco during this period were Archicofradía, San Juan de Dios, and Asunción. ${ }^{\circ}$ The augmentation of Spanish landholdings did not go unnoticed by the Indians, and even in the early colonial period the villagers set about in the courts to

${ }^{3}$ For the most extensive discussion of the agrarian movement in the nineteenth century see Silva Herzog. However, the author, with the exception of the Rio Verde incident, did not examine the uprisings studied in this essay.

${ }^{9}$ Bibliotheque Nationale, Paris, No. 205, fol. 3f; cited by Charles C. Gibson, Tbe Aztecs Under Spanish Rule, (Stanford, 1964), 141-142.

${ }^{5}$ Gibson, The Aztecs, 290-291. 
defend their acreage. The pueblos found it convenient to claim communal village ownership, even when the parcels in question had been privately held, because the titles indicating municipal ownership were easier to establish in the Spanish records which often listed towns as sovereign, but failed to mention the names of individual holders. In this way, as a means of defense, communality in pueblo life was exaggerated beyond what it had actually been. ${ }^{\circ}$ This stress on individual village rights laid the basis for the later agrarian demand that the municipio libre, or politically free and economically independent village, become the fundamental political-social unit of the nation. ${ }^{7}$ But, despite their vigilance and energetic self-defense, the villages could not hold off the conquerors.

By the close of the colonial epoch the process of land polarizationthat is, impoverished villages vis à vis the great estates-was quite advanced, and this process continued throughout the nineteenth century. ${ }^{8}$ Moreover, the population of the villages was continuing a comback that began in the early eighteenth century. ${ }^{9}$ This resurgence of the indigenous population created new pressures upon the pueblos and the reduced amount of land that remained available to their inhabitants. The close of the colonial period, however, signals the introduction of yet another element-the political revolutionary. The fiery rhetoric of the struggle for independence stirred up the campesino masses, as the following attracted by Hidalgo and Morelos indicates. The problem of land distribution was now broached in the national political arena for the first time, and it would hereafter play a significant role. It was within this milieu of the omnipresent great estate and the increasing, impoverished and landless population in the countryside that an agrarian ideology was formulated that became the basis of the Chávez López insurrection which erupted at Chalco in 1869.

In 1865 Chávez López, who was living near Chalco, had come under the tutelage of utopian socialist organizers from Mexico City who had gone to Chalco in order to politicize the campesinos and to start an

${ }^{6}$ lbid., 407-409.

${ }^{7}$ Venustiano Carranza tried to capitalize on this sentiment during his address to the 1916-1917 constitutional convention in Querétaro. See Diario de los Debates del Congreso Constituyente, (México D. F., 1917), Volume 1, 266.

${ }^{8}$ For a description of the land acquisition process in the colonial period see Francois Chevalier, Land and Society in Colonial Mexico; The Great Hacienda, (Berkeley and Los Angeles, 1963). For an excellent discussion of hacienda expansion in nineteenth century Morelos see John Womack, Zapata and the Mexicam Revolution, (New York, 1969), 37-66.

' Gibson, The Aztecs, 139-142. 
agrarian communal movement. Two of the principal socialist activists in Mexico, Plotino Rhodakanaty and Francisco Zalacosta, undertook this endeavor. Rhodakanaty, a teacher of Greek-Austrian parentage, had emigrated to Mexico for the expressed purpose of developing an anarchist agrarian movement based upon his interpretation of Fourier, Proudhon, and Bakunin. ${ }^{10} \mathrm{He}$ explained his plan as ". . . the undoing of the relationship between the state and the economic system, the reorganization of property, the abolition of politics and political parties, the complete destruction of the feudal system, and the expedition of agrarian reform laws. This is socialism and this is what we want." ${ }^{11}$

Zalacosta, a firebrand revolutionary and student of Rhodakanaty, had previously been involved with the organization of mutualist societies in Mexico City. ${ }^{12}$ Rhodakanaty and Zalacosta operated a school in Chalco -the Free School, or the School of Englightenment and Socialism-in order to make revolutionaries of the campesinos there. The training program consisted of reading, writing, public speaking, and anarchist and revolutionary theory. ${ }^{13}$ The theory called for the formation of agrarian collectives which would bring about a form of socialism described as

... liberty, equality, and fraternity, to which we add unity. Liberty means ... freedom from all restriction. ... Equality means equal rights before the law, the equality of social positions within each nation, equal distribution of wealth, and equality of conscience before the universal moral order represented by humanity. ... .

Fraternity means solidarity achieved by means of love and philanthropy between all members of the great human family. . . U Unity is the convergence of all individual interests with those of the general well being. Unity is the joining together for all time, by means of the association, of the talents of both labor and capital. ${ }^{14}$

Chávez López was soon recognized by Rhodakanaty and Zalacosta as

${ }^{10}$ For an intensive analysis of the European ideological and organizational infuence upon Mexican anachism and the nineteenth-century agrarian movement, the differences between rural and urban anarchism, biographical data on the leaders of the movement, and the reactions of the Mexican "establishment" see John M. Hart, "Anarchist Thought in Nineteenth Century Mexico," Ph.D. dissertation, the University of California at Los Angeles, December, 1970.

11 Plotino C. Rhodakanaty, "Lo Que Queremos," El Hijo del Trabajo, (México D. F.), No. 92, April 28, 1878.

12 "Pequeña Biografía de Plotino C. Rhodakanaty," La Paz, (Chilpancingo, Guererro, México), cited by José Valadés in "Precursores del Socialismo Antiautoritario en México," La Protesta, (Buenos Aires, Argentina), May 22, 1928, 409.

${ }_{13}$ Juan Hernández Luna, "Movimiento Anarco-Fourierista Entre El Imperio Y La Reforma," Cuadernos de Orientación Politica, Number 4, (México D. F., 1956), 19-20. ${ }_{14}$ Rhodakanaty, article in El Socialista (México D. F.), Number 178, May 28, 1876. 
their best student, and they spent a good deal of time working with him during the next few years. ${ }^{15}$

In 1867 Rhodakanaty, satisfied that the school was succeeding in its program and not wishing to be present for the planned revolutionary violence, left Chalco because " the school is no longer a school, but now is an association por y para la libertad." ${ }^{16}$ The influence of Rhodakanaty and Zalacosta upon Chávez López had been profound. The latter demonstrated that he had learned his mentors' lessons well when he wrote: "I am a communist-socialist. I am socialist because I am the enemy of all governments, and I am communist because my brothers wish to work the lands in common." ${ }^{17}$

Shortly after Rhodakanaty's departure, Chávez López left Chalco and went south into the northwestern sector of the state of Puebla. He found that agrarian unrest there had reached an acute stage and that the campesinos were desperate enough to resort to insurrection. He asked Zalacosta for his opinion regarding the instigation of a revolt. "I have finally arrived here, there is much discontent among the brothers because the generals want to take over their lands. What would you think of it, if we made the socialist revolution?" ${ }^{18}$ Without waiting for a response, Chávez López began organizing a rag-tag campesino army recruited from the tri-state area. His activities soon attracted the attention of the government, and federal troops began scouring the countryside for him. Although outnumbered and poorly armed, he never lost his enthusiasm. "We are surrounded by a batallion, it is of no consequence. Long live socialism! Long live liberty!" ${ }^{19}$ Chávez López eluded the troops and returned to Chalco. Then, on April 20, 1869 , he issued his Manifesto calling the Mexican people to arms in order to establish a new agrarian order and to resist what was described as the oppression of the upper classes and the political tyranny of the central government.

The Manifesto was an important document in the development of an

${ }^{15}$ Letter, Rhodakanaty to Zalacosta, Chalco, September 3, 1865, Archivo Judicial del Estado de Querétaro.

${ }^{16}$ Letter, Rhodakanaty to Zalacosta, Mexico City, November 1868, Archivo Judicial del Estado de Querétaro.

${ }^{17}$ Manuel Díaz Ramírez, Apuntes Históricos del Movimiento Obrero y Campesino de México 1844-1880, (México D. F., 1938), 35.

${ }_{18}$ Letter, Julio Chávez López to Zalacosta, Puebla, January 13, 1869, Archivo Judicial del Estado de Querétaro.

${ }^{19}$ Letter, Chávez López to Zalacosta, April 18, 1869, Archivo Judicial del Estado de Querétaro. 
agrarian ideology not only because it introduced the European socialist concept of class struggle into the Mexican agrarian movement, but also because it placed the hardships endured by the campesinos within an historical context and identified culprits. It called for the revered principle of autonomous village governments to replace the sovereignty of a national government which was viewed as the corrupt collaborator of the bacendados. This anarchist-like support of the local municipality as the ultimate dispenser of justice in the countryside has been a common thread in many agrarian revolutions. As Eric Wolf observes, "The peasant utopia is the free village, untrammeled by tax collectors, labor recruiters, large landowners, officials ... for the peasant, the state is a negative quantity, an evil, to be replaced in short shrift by their own 'homemade' social order. That order, they believe, can run without the state; hence, peasants in rebellion are natural anarchists." 20

The ideological content of the Manifesto was also significant because of the men who collaborated in writing it. Rhodakanaty was a European ideologue, who, working with a number of exiled Spanish radicals, had a profound influence upon the developing ideology of the Mexican agrarian movement. Their ideology, which was detailed in the workingclass press during the 1870 's, echoed the sentiments of contemporary Spanish Bakuninists who were organizing large numbers of peasants in Andalusia and Catalonia. The success of this appeal in the Mexican countryside as well is not surprising, given the similar conditions. The Manifesto was a dramatic expression of the new class-struggle type of ideology that was emerging from the increasingly desperate Mexican agrarian movement.

The hour of understanding for men of good heart has arrived; the day has come for the slaves to rise up as one man reclaiming their rights that have been stolen by the powerful few. Brothers! The moment has arrived to restore the countryside, to ask explanations of those who have always demanded them of us; it is the day to impose obligations on those who thought they only had rights.... Those that have taken advantage of our physical, moral and intellectual weakness are called latifundistas, terratenientes or bacendados. Those of us who have patiently let them grab what belongs to us are called workers, proletarians or peones. We peones have given our lives and interests to the bacendados and they have subjected us to the greatest possible abuses; they have established a system of exploitation by which means we are denied the simplest pleasures of life. How does this system of exploitation operate? It is a system that dedicates itself exclusively toward blighting the very existence of the peon. Our parents were acquired by the hacienda at the wage of one real per working day. It

${ }^{20}$ Eric R. Wolf, Peasant Wars of the Twentietb Century, (New York, 1968), 294-295. 
was not possible to survive on this amount because the stores located on the haciendas sold their goods at greatly inflated prices; much more expensive than the cost of things that month by month and year by year we make by hand. The costs of these store bought articles created debts that were charged to our parents. How would they be able to settle debts like those when they were earning no more than one miserable real for a day's work? . . .

When we came into this world we were faced with the debts of our parents, they were passed on to us. In this way we became slaves obligated to continue working in the same place, under the same system, with the pretense of paying the now famous debts. But our wages were never increased, nor was credit ever granted to us and we found ourselves in the same situation as our parents.

And who is it that has cooperated to keep us muted, in humiliation, in ignorance and in slavery? The Church, especially the Church. . . . Its hypocritical missionaries. . . . The Friars who say everything is in vain. ... The priests who have deceived us. ... Let religion reign, but never the Church and even less the priests. ... If the priests are evil so are all those men who give orders. What can we say about that which has been given us and called government and which in reality is tyranny? Where is the good government? . . .

The bacendados have been the strong men, who relying upon the military that they themselves maintain in order to safeguard their properties, have laid claim to possessions in whatever places they have desired, and they have done so without effective protests. What do we want? ... We want: the land in order to plant it in peace and harvest it in tranquility; to leave the system of exploitation and give liberty to all in order that they might farm in the place that best accommodates them without having to pay tribute; to give the people the liberty to reunite in whatever manner they consider most convenient forming large or small agricultural societies which will stand ever vigilant in the common defense, without the need of outsiders who give orders and castigate.

Fellow Mexicans! This is the simple truth with which we will win one way or another in order to bring about the triumph of liberty. We are going to be persecuted, maybe shot full of holes, but this is not important because we carry our dreams with us. What choice do we have with our lives? Death is better than the perpetuation of oppression and misery. As Liberals we reject the oppression. As socialists it wounds us. As men we condemn it. Abolition OF THE GOVERNMENT, ABOLITION OF EXPLOITATION!

We want land, we want order, we want liberty. We must emancipate ourselves from all of our miseries, we need peace and stability. Finally, what we need is the establishment of a social contract among men based upon mutual respect. Long live socialism! Long live liberty! ${ }^{21}$

${ }^{21}$ Chávez López, Manifesto a Todos Los Oprimidos y Pobres de México y del Universo, Chalco, April 20, 1869; text from Hernández Luna, "Movimiento AnarcoFourierista," Cuadernos, Number 4, 19-25. 
The obstacles encountered in the attempt to achieve the ideological goals expressed in the Manifesto were overwhelming. Chávez López was apprehended without a fight and taken to Chalco by federal forces a few days after he issued his manifesto. His campesino friends liberated him on May 1, however, and routed the handful of soldiers who were supposed to be detaining him. After his escape, Chávez López and his companions went into the nearby hills, where they were joined by increasing numbers of campesinos. After sufficient recruits had joined them, the insurgents successfully moved against the town and hacienda of San Martín Texmelucan, located on the main road between Chalco and Puebla City. The federal troops they encountered were scattered, leaving their weapons behind. Chávez López collected all the money he could find in the town and then, setting a precedent to be followed in later times, he burned the municipal archives.

After reading his manifesto and explaining his ideology, gathering more followers and regrouping his army, he next advanced upon the town of Apizaco in Tlaxcala and once again routed the garrison, burned the municipal archives, and collected available money and arms. Reconnoitering and planning strategy, Chávez López understood that his movement had to have a widespread base of support in order to succeed; with this objective in mind, he sent a lieutenant, Anselmo Gómez, with a contingent of fifty men east into the state of Veracruz in order to secure a base there. In the meantime, Chávez López with the main force, which now numbered about 1,500 still poorly armed men, moved to the north toward the state of Hidalgo. ${ }^{22}$

As he advanced, Chávez López continued his attempts to gain the support of the people in the countryside by reading and explaining the ideology of his manifesto. He also demonstrated the practical application of the Manifesto by seizing haciendas and redistributing the land to the campesinos. ${ }^{23}$ In this drive to the north, he continued to attract new recruits, to burn municipal archives, and to seize considerable amounts of money; but he failed in his attempts to requisition sufficient arms, and this would be his undoing. The contingent under Anselmo Gómez that had moved east also enjoyed success in its recruiting efforts; and by June 11 when it captured the town of Chicontepec in Veracruz, it numbered about 150 men. The government jefe in Chicontepec provided us with an insight into the reaction of the well-to-do elements

\footnotetext{
22 Díaz Ramírez, Apuntes Históricos, 36.

${ }^{23} \mathrm{lbid}$, see also, Antonio Díaz Soto y Gama, La Revolución Agraria del Sur y Emiliano Zapata su Caudillo, (México D. F., 1961), 29; and Hernández Luna, "Movimiento Anarco-Fourierista," Cuadernos, Number 4, 25-26.
} 
of society to Chávez López's ideology and his motley army when he informed the minister of war that ". . . the bandit Anselmo Gómez leading 150 men has taken the town and is committing all manner of outrages against private property while proclaiming to the people his refusal to recognize any form of government." ${ }^{24}$

Chávez López in the meantime had moved past his own home town of Texcoco to the relatively large town of Actopan, located seventeen miles northwest of Pachuca. His forces, however, were attacked and defeated before they could launch their assault on the town. Federal troops took him prisoner and conducted him to Actopan; then, when it was ascertained that his followers no longer constituted a threat, he was returned to Chalco, where the government of Benito Juárez ordered him executed by firing squad in the courtyard of the Escuela del Rayo $y$ del Socialismo on the morning of September 1, 1869. One brief resume of this episode relates that Chávez López shouted "Long live socialism!" as he was shot-a believable story in view of his past behavior. ${ }^{25}$ The eventual fate of Anselmo Gómez and the contingent of men who had invaded the state of Veracruz is unknown. ${ }^{26}$

A significant aspect of the Chávez López movement was the conscious appraisal by the campesinos themselves of the ills that beset their society. Previous "agrarian uprisings" had usually been led by relatively well educated, liberal, and financially well-to-do military leaders who promulgated "plans"; or they were genuine campesino insurrections which articulated little and merely resulted in land seizure. With the advent of the Chávez López uprising, the historian encounters for the first time in Mexico a campesino movement which called for the reordering of society and advocated the formation of "agricultural societies which will stand ever vigilant in the common defense, without the need of outsiders who give orders and castigate." ${ }^{27}$ The challenge he presented was continued by the agrarian uprisings that originated in the same area during the 1870 's and 1880's. The call for "agricultural societies," then, was the harbinger of the Municipio Libre, which would become a regular part of agrarian terminology in the 1870's and such a sancrosanct image by the twentieth century that the "First Chief of the Revolution," Venustiano Carranza, in his address to the Consti-

${ }^{24}$ Díaz Ramírez, Apuntes Históricos, 36.

25 Ibid., 36-37.

${ }^{26}$ Unfortunately, a great deal of material and information about the activities of Rhodakanaty, Zalacosta, Chávez López, Gómez and others involved with the Escuela del Rayo y del Socialismo was lost when the school records were destroyed in a fire.

${ }^{27}$ Chávez López, "Manifesto," from Hernández Luna, "Movimiento AnarcoFourierista," Cuadernos, Number 4, 24. 
tutional Convention at Querétaro in 1916, pledged, in an attempt to gain delegate backing for his program to give the Municipio Libre his full support as the "political" and "economic" basis of free government.

During the years that followed the demise of Chávez López, agrarian adherents began an active campaign on behalf of the campesinos through the medium of the Mexico City working-class press. ${ }^{28}$ Radicals, many of them anarchists, continued to develop the agrarian ideology by speaking of cooperative agrarian colonies independent of governmental interference and reinforcing their members' sense of local patriotism. One of the best examples of this type of agrarian during the 1870's was José María González, who said:

They will ... purchase land and settle colonies and a sense of patriotism will develop for the colony to which one is born. Then, when prosperity smiles on the colony, there will be schools for the instruction and education of both the children and adults which will be attended perfectly and will produce a higher morality that will ... eliminate the vices that affect other societies. By this means one arrives at not having the need of a government, with its imperfect schools, its manner of calling to the fore the emotions and wars caused by hunger, and which is the cause for the multitudes of criminals found in our jails. ${ }^{30}$

Describing goals based upon ideology was easier, however, than successfully formulating a realistic plan to bring them about. One of the first plans was advanced by González in 1876:

[A] cooperative company can be formed with ample capital by means of installment payment plans. With the money obtained in this manner one can establish stores stocked with high priority consumer goods.

Once the funds are sufficient ... the worker can continue independently of the capitalist. ... By the same means land is then purchased in order to form colonies. ... (After success) [We] believe that the inferior status ... of the middle-class woman would disappear forever, that beggary would have no reason for being, that the abuses perpretrated by the government upon the working class would be ended, that the moral character of the workers would be revealed and that all people would enjoy respect because they would be part of a real social entity. ${ }^{81}$

González then proposed a program in which a group of one hundred associates, by saving one hundred pesos each would amass 10,000 pesos

28 Diario, Volume 1, 266.

${ }^{29}$ The principal periodicals involved were El Socialista, El Hijo del Trabajo, El Obrero Internacional, (México D. F.), and La Internacional, (México D. F.).

30 José María González, "Las Sociedades Mutualistas," El Hijo del Trabajo, Number 16, August 6, 1876.

s1 lbid. 
plus interest over a two year period. This capital was to be used to purchase land and equipment to begin an agrarian collective. González concluded with a credulous appeal for thousands of agrarians and workers to join the project, which he predicted would " amaze" people. González was widely read and helped to popularize developing agrarian concepts. His most significant ideological contribution was the introduction into Mexico of the idea of autonomous agrarian cooperatives with control over cash resources which were to be used for development and the provision of necessary farming implements.

The Mexico City advocates of agrarian reform were almost obsessed during the 1870 's with two prolonged agrarian struggles that resulted in the expulsion of campesino families from disputed land. Contrary to the emerging agrarian ideology, the bacendados involved in these cases were expanding their territories at the expense of two campesino pueblos. The agrarian essayists in the Mexico City working-class press became nearly hysterical in their denunciations, while whipping up the emotions of their supporters and calling their rivals thieves and robbers. ${ }^{33}$ But during the struggles that ensued, the agrarians came to believe that they had not gone far enough and that their program was inadequate.

A major crisis developed when González charged that Iwes Limantour, the proprietor of the Hacienda La Tenería in the state of Mexico, had forcibly taken the farming lands of the pueblo San Simonito Tlacomulco in 1869 without legal sanction. In 1876 the campesinos, hopeful that the new president, Díaz, would help them, petitioned him for return of the land. But by 1877 Limantour, who had supported former President Lerdo, had proven his ability to survive political upheaval by gaining the support of the Díaz regime in the settlement of the dispute. Limantour kept the property, this time with the sanction of the courts. González reacted by printing the pathetic petition sent Díaz by the pueblo and then summarized his feelings:

... [A]s one can see from this document, Sr. Limantour has committed an unjustifiable abuse. It certainly was not necessary for him to increase his holdings with the lands of the San Simonito pueblo. . . .

Well, then, do we have to wait until the powerful might feel remorse, in order that without violence, or when with a sense of justice, they might return that which does not belong to them?

That is to wait in vain! ${ }^{33}$

${ }^{32}$ For examples see La Internacional, Number 4, July 28, 1878; González, "También Son Hombres," El Hijo, Number 61, September 23, 1877; and González and others in the series entitled "La Cuestión Indígena," that was carried by $E l$ Hijo throughout 1877-1878.

${ }^{33}$ González, “AApeo y Deslinde de Terrenos! ¡Abajo la Usurpación!,” El Hijo, Number 67, November 4, 1877. 
For nearly two years the agrarian advocates in Mexico City campaigned for the return of lands that had been lost by a campesino community to the Hacienda de las Bocas in San Luis Potosi. In fact, it was the series of incidents on the Hacienda de las Bocas that led to some of the most fierce attacks against the Díaz government. González led the attack, referring to the regime as a group of "oppressors and gangsters" who used the rurales to support the bacendados. ${ }^{34}$ According to the working-class press accounts (the other newspapers ignored the land disputes), the pattern of these land acquisitions was almost classical in nature. They claimed that in 1864 the bacendados had obtained a series of court decisions based upon the Ley Lerdo that adjudicated the land to them. With the courts' decision, or perhaps before the courts' decision, they had obtained the support of the local, state, and national authorities. The bacendados involved were the "wealthy and powerful "Farías family. ${ }^{35}$ The campesinos, who had originally occupied the land early in the previous century, were legally declared squatters. This new settlement, a common phenomenon as the rural population continued to increase during the century, had already received recognition in 1792 as the pueblo of Abualulco; and the town archives indicated that the village church was constructed in that year. During the court proceedings, none of the town's citizens could provide testimony regarding the legal rights under which the town had been established; and they possessed no documentary proof. They were then expelled from the property. ${ }^{36}$

Later, during the tripartite civil war between Díaz, Lerdo, and Iglesias, there was a general feeling among agrarians that Díaz had at least partially adopted their ideology because they thought that he had promised land reform to the poverty stricken peones of the Mexican countryside. González, for example, referred to this commitment when he wrote: "[T] he plan of Tuxtepec promised us the independence of the municipality, but it was just a promise to lure us." ${ }^{37}$ The former citizens of Abualulco had acted upon the assumption that the land was going to be returned to them and reoccupied it. ${ }^{38}$ Unfortunately for

\footnotetext{
${ }^{34}$ González, "La Cuestión Indígena, (Hacienda de las Bocas)," El Hijo, Number 71, December 2, 1877.

${ }^{35}$ La Internacional, Number 8, August 25, 1878.

${ }^{36}$ Report from Juan Othon, Señor Secretario de la Prefectura Superior Política del Departmento de San Luis Potosí, January 1864, cited by González in "La Cuestión Indígena (Hacienda de las Bocas)," El Hijo, Number 72, December 9, 1877.

${ }^{37}$ González, article in El Hijo, Number 79, January 27, 1878.

${ }^{38}$ This was probably done in 1876 although no record of the exact date of the event exists.
} 
them, by 1878 the Díaz government and the local and state authorities had decided against them. The campesinos were once again forcibly removed, their buildings razed, and their belongings lost. ${ }^{39}$

The contents of a telegraphic message sent from the rurale official on the scene was read by La Internacional's correspondent, Moctezuma; he forwarded the report to his paper, and it appeared in the next day's edition:

"Commandant F. Rodríquez: Yesterday the removal of morenos began from the Rancho San Vicente, upon the orders from the owners of the Hacienda de Bocas (sic), today the expulsion of all the families was completed. Joaquín Flores." ${ }^{40}$

The message caused a furor among Mexico City's agrarians. Outraged, La Internacional's editors commented:

Six hundred families have been thrown off of this land in the Rancho San Vicente, upon the orders of the usurpers from the Hacienda de Bocas (sic).

This horrible act is nothing more than a repetition of what previously occurred in 1869 when this vile hacendado threw out others, including old men, women, and children. . . .

$\therefore$ The rich, with but few and honorable exceptions, lead lives filled with vice and crime . . . at the price of onerous sacrifices on the part of the workers. But when the workers realize this, they will then be able to emancipate themselves from the rule of private capital by joining associations and creating cooperative societies. letario! $^{41}$

The growing animosity of agrarians toward the Díaz regime was indeed reaching the boiling point. By 1877 González and others were calling for a mass uprising, La Revolucion Social, in their articles that teated the disputes betweencampesinos and bacendados. ${ }^{42}$ But the most important result of the agrarian disputes during the 1870's was the emergence of a more sophisticated agrarian ideology.

By 1878, with years of debate and hundreds of newspaper articles

${ }^{89}$ González, "La Cuestión Indígena (Hacienda de las Bocas)," El Hijo, Number 73, December 16, 1877.

40 Communique from Joaquín Flores to Commandant F. Rodríquez according to La Internacional reporter Moctezuma and telegraphed to La Internacional on July 20, 1878. It was published in La Internacional, Number 3, July 21, 1878.

41 Editorial in La lnternacional, Number 4, July 28, 1878.

42 For examples see González, "¡Apeo y Deslinde de Terrenos! ¡Abajo la Usurpación!," El Hijo, Number 67, Ncvember 4, 1877; and "De Rodillas, Miserables!," El Hijo, Number 55, Augusז 12, 1877. 
behind them, the agrarians had developed a program that seemed elaborate in contrast to the ideological simplicity of Chávez López. Zalacosta, the editor of La Internacional, endorsed and printed a plan which he said was the proposal of La Social, an anarchist-Bakuninist organizing group that claimed 62 branch sections scattered throughout Mexico. ${ }^{43}$ The plan's agrarian program called for dissolution of the national government, autonomous municipalities, an agrarian law to provide for the measuring and demarcation of desamortized lands, liquidation of urban interests and capital in the countryside, gradual leveling and equalization of property ownership, ultimate abolition of the wage system and meanwhile the procurement by means of strikes of higher agricultural wages, the formation of territorial banks to secure the sale of agricultural products, and the Falansterio Societario for the regulation of both urban and agricultural labor. ${ }^{44}$

Zalacosta despaired of government cooperation in his agrarian plan and formed a coordinating committee, the Gran Comité Central Conmunero, to help provoke revolution in the countryside. Then, armed with the program of La Social-La Internacional and the Manifesto of Chávez López, he went to Chalco, where, by reading his proclamations to the peones and reminding them of their grievances, he managed to stir up a campesino rebellion. From late 1878 to early 1880 , during a period of eighteen months, Mexico was subjected to a series of agrarian clashes between Zalacosta and hundreds of his followers on one side and the Fcderal army and to a lesser extent the rurales on the other. With the help of the Gran Comite Central Conmunero, emmissaries were sent over the countryside; and the revolt spread from the Chalco-PueblaMorelos area to the north as far as San Luis Potosi, Coahuila, Durango, and Chihuahua, and west to Michoacan; numerous haciendas and towns fell victims to pillage. ${ }^{45}$ Zalacosta was finally apprehended near Querétaro, where he was detained and eventually executed. ${ }^{40}$ The wave of unrest rose and fell until 1884, when the government once again gained control of the situation. ${ }^{47}$

In the midst of the agrarian turmoil that gripped most of central Mexico, a new agrarian proposal was promulgated which was by far the most complex and sophisticated agrarian document yet seen. It

${ }^{43}$ La Internacional, Number 8, August 25, 1878; and Number 14, October 6, 1878.

${ }^{44}$ La Internacional, Number 2, July 14, 1878.

${ }_{45}$ Díaz Soto y Gama, La Revolución Agraria, 43-47; and Díaz Ramírez, Apuntes Históricos, 63-66.

${ }_{46}$ Interview, José Valadés, Oaxtepec, México, November 6, 1969.

47 Ibid.; see also Díaz Soto y Gama, La Revolución Agraria, 52-53. 
marked the apex in the development of nineteenth-century agrarian revolutionary ideology. The proposal, known as the Ley del Pueblo, was submitted by Colonel Alberto Santa $\mathrm{Fe}$ by means of the workingclass press. ${ }^{48}$ Although one historian has described Santa Fe as "half Bakuninist-half Marxist," ${ }^{49}$ he had probably never heard of Marxist ideas, since they were not disseminated in Mexico until the 1880 's; ${ }^{\text {so }}$ Bakunin, however, was a frequent topic in the pages of the Mexico City working-class press with which Santa $\mathrm{Fe}$ had a close relationship. ${ }^{.1}$ Porfirio Díaz called him a "Communist"; ${ }^{52}$ and the reason for this reaction is not hard to find, since the preamble of the Ley del Pueblo stated that the Ley was based upon the concept of human social and spiritual equality. Its program called for the distribution of parcels of land to the extent of 276 rods in length by 184 in width per minor son to each campesino family in Mexico as long as the family's total capital and property did not exceed 3,000 pesos. The municipios would be the authorities who would determine which lands were to be seized from the haciendas. To obtain compensation, the bacendado was to present a receipt for his lands to the nearest office of a Banco Agrícola $y$ Industrial, which in open and public hearings would determine the property's value. The banco, which would be required to have at least one branch in every state of the Mexican union, would keep a record of how much territory had been claimed by the pueblo in order to determine when, according to its population, sufficient acreage had been acquired. The ayuntamiento municipal or village council was charged with the responsibility of individual or communal plot distribution in accordance with local tradition. The recipient was required to repay the agreed upon value of the land to the agricultural bank at a rate of 10 per cent per year plus 6 per cent interest on the unpaid principal for ten years. The land title could not be transferred to another individual until the terms of the agreement had been met. Further, the

${ }^{48}$ Alberto Santa Fe, "La Ley del Pueblo," La Revolución Social, (Puebla), Number 2, December 18, 1879; and El Socialista, Number 30, August 4, 1878.

49 Victor Alba, Las Ideas Sociales Contemporáneas en México, (México D. F., 1960), 103.

${ }^{50}$ In 1883 El Socialista became the first Mexican journal to demonstrate an interest in Marxism. It began by publishing a matter-of-fact obituary of Marx (El Socialista, Number 25, April 11, 1883). A year later the text of the Communist Manifesto appeared for the first time in a Mexican newspaper (El Socialista, Number 39, June 12, 1884). Finally, in 1885 , an article by Marx himself was printed (Carlos Marx, "La Lucha de las Clases," El Socialista, Number 40, July 19, 1885).

${ }^{51}$ Santa Fe had worked with Rhodakanaty, González, and Zalacosta on the staffs of El Hijo and La Internacional.

${ }^{52}$ Letters, Santa Fe to the Editor, El Hijo, Number 151, June 15, 1879, and Number 174, November 23, 1879. 
agricultural bank was charged with the responsibility of providing low interest loans to the campesinos through the municipal councils for the purchase of agricultural equipment, seeds and other necessary farming implements. ${ }^{53}$

Because of Santa Fe's persistent advocacy of his Ley, his association with the fugitive Zalacosta, and the use of his plan by the revolutionary General Miguel Negrete in Morelos, he was arrested in Puebla. ${ }^{54}$ The government was given further incentive to make the arrest by his open communications with agrarian revolutionaries in Guanajuato and Michoacan who were already combating the federal army in the field.5 Accused of being a "communist," he was placed in the prison of Santiago Tlalteloco in Mexico City on June 8, 1879.56 He was later sent into the north into exile. Chastized, years later he was elected to the Congress as a pro-Díaz deputy from Durango. ${ }^{57} \mathrm{He}$ proved to be a repentant sinner who never again muddied the water.

In 1879 the Ley del Pueblo inspired a serious rebellion led by General Miguel Negrete in Puebla, the Chalco area, Morelos, and Guerrero. ${ }^{58}$ Negrete explained:

I even opposed Juárez . . . because he failed to come to the aid of the people, then Lerdo, and now Díaz; because of his betrayal of the people after raising their hopes, by surrounding himself with a gang of accomplices, not friends.

I have fought whenever I saw public liberties in danger, and the workers of the city and countryside, as of now, are worse off than ever .... [T] he tyranny will end. ... I hope to lead the last revolution, the one which will end these conditions. ${ }^{58}$

Between 1868 and 1890 Negrete was a potent force in the vast mountainous area extending across the states of Puebla, Morelos and Guerrero. ${ }^{\text {Bo }}$ He had long supported revolutionary sociopolitical programs and had consistently sided with the urban labor and agrarian

${ }^{53}$ Santa Fe, "La Ley del Pueblo," La Revolución Social, Number 2, December 18, 1879; and El Socialista, Number 30, August 4, 1878.

${ }^{54}$ Letters, Santa Fe to the Editor, El Hijo, Number 151, June 15, 1879, Number 174, November 23, 1879, and El Socialista, Number 98, January 15, 1880.

${ }^{55}$ La Revolución Social, October 17, 1878, and October 24, 1878; see also Díaz Soto y Gama, La Revolución Agraria, 50-53.

${ }^{56}$ Letters, Santa Fe to the Editor, El Hijo, Number 151, June 15, 1879, and Number 174, November 23, 1879.

57 El Socialista, Number 32, August 29, 1886.

58 "Don Miguel Negrete," El Hijo, Number 220, October 10, 1880.

59 Miguel Negrete, article in El Socialista, Number 70, June 9, 1879.

${ }^{60}$ See "Don Miguel Negrete," El Hijo, Number 220, October 10, 1880, and El Hijo del Abuizote, (México D. F.), Number 249, November 2, 1890. 
movements in their relations with the governments of Juárez, Lerdo, and Díaz. ${ }^{61}$ He had first acted against Juárez as early as 1866 , because he and his confederate, General García de la Cadena, both of whom were leading generals in the Liberal resistance against the French, considered Juárez too conservative. ${ }^{62}$ This was done despite the fact that Negrete was the chief field commander of the Juárez army; ${ }^{63}$ the plot fell through because of the opposition voiced by Generals Francisco Naranjo and Juan N. Sáenz. ${ }^{64}$ It is clear from the record that Negrete was no ordinary provincial caudillo. He had managed literally to alienate himself from the compromisers and "practical men" with his consistent espousal of agrarian and urban labor reform.

In 1869 he conducted a campaign against government troops in the Puebla area immediately adjacent to Chalco at almost the same time that the federal forces found the Chávez López uprising out of control. ${ }^{65} \mathrm{He}$ then supported the insurrectionists at Chalco in 1879 who had rallied to Zalacosta. ${ }^{68}$ His support of the Ley del Pueblo in 1879-1880 was entirely consistent with his record. He barely managed to escape arrest in Puebla when federal troops surpised him and some of Santa Fe's supporters. The Mexico City newspaper El Hijo del Trabajo commented: "God save Don Miguel from the claw." " 7 In 1880 Negrete helped to spread the ideology of the agrarian movement when he issued his own revolutionary agrarian program which called for the emergence of the autonomous and sovereign municipio libre to distribute land and determine the outcome of the long-standing agrarian dispute. ${ }^{68}$ He continued to hold out against Díaz until the early 1890's when advanced age forced him to abandon the struggle. ${ }^{69}$

In 1880 Rhodakanaty returned to Chalco with the intention of

${ }^{61}$ Negrete, article in El Socialista, Number 70, June 9, 1879.

${ }^{62}$ Ibid: see also the letters, General González Ortega to Negrete, New York, Septcmber 10,1866, and Silvestre Aranda to Benito Juárez, Chihuahua, Chihuahua, April 22, 1866, Archivo Juárez, Biblioteca Nacional, México D. F.

${ }^{63}$ Diario del Imperio, (México D. F.), Number 136, June 14, 1865.

${ }^{84}$ Letters, General Francisco Naranjo to Negrete, Villa Aldama, Nuevo León, January 27, 1866, February 6, 1866, and February 7, 1866; also, General Juan N. Sáenz to Negrete, February 6, 1866, and February 7, 1866 (point of dispatch unknown); Archivo Juárez, Biblioteca Nacional, México D. F.

${ }^{65}$ Five letters, Negrete to Colonel Pedro Villegas, Santa Ana, Puebla, February 14, 1869; also letter, Negrete to Lt. Colonel Melitrón Galarza, February 14, 1869, Chiaulla, Puebla; Archivo Juárez, Biblioteca Nacional, México D. F.

68 “Don Miguel Negrete," El Hijo, Number 220, October 10, 1880.

${ }^{67}$ lbid.

${ }^{68}$ Negretc, “Municipio Libre," El Hijo, Number 200, May 23, 1880.

${ }^{89}$ Letter, Negrete to Porfirio Díaz, January 30, 1893, Archivo Histórico de la Defensa Nacional, Expediente X/111.2/15-709, Primer Tomo, Document \#499. 
reopening his escuela only to find the task rendered hopeless by the combined hostility of the government, the local bacendados, and Tiburcio Montiel, who had founded a large campesino organization, the Liga Agrária de la República Mexicana. ${ }^{70}$ The Liga, which held regular meetings and sponsored legal action against the territorial encroachments of bacendados had members in the states of Hidalgo, Mexico, Morelos, and Puebla. ${ }^{71}$ Montiel had been active in the agrarian movement since the early 1870's, and he had assisted Zalacosta in the formation of the Gran Comite Conmunero in $1876 . .^{72}$ In 1878 he had written a particularly aggressive article in El Socialista. His essay was a condemnation of agrarian injustice and cited specific attacks, land seizures, and even instances of cattle rustling committed by haciendas against pueblos. He concluded with the assertion that, if his resistance to hacendados" aggressions was "comunismo," then so be it. ${ }^{73} \mathrm{He}$ obviously regarded Rhodakanaty as a rival when the latter returned to Chalco. Discouraged, Rhodakanaty returned to Mexico City; he finally gave up and returned to Europe in $1886 .{ }^{74}$ Unfortunately for Montiel, his dispute with Rhodakanaty attracted too much attention to him; the government identified him as a cohort of Santa $\mathrm{Fe}$ and Zalacosta and arrested him in August 1881. After a short-lived jail release, during which he joined Rhodakanaty and others as a temporary editor of El Socialista, the government again arrested Montiel and sent him into exile at $\mathrm{La} \mathrm{Paz}$, Baja California. In the meantime, the ever troublesome campesinos at Chalco who had supported him by resorting to the seizure of contested lands were violently suppressed by the federal army. ${ }^{75}$

Although small agrarian clashes continued to occur throughout the central area of Mexico until 1910 the historical record does not reveal any major attempts made by the campesinos or pueblos of Chalco or the nearby areas of Morelos and Puebla to redress their grievances outside the legal channels. The last major agrarian uprising of the nineteenth century occurred at nearby Papantla in Veracruz, where, despite overwhelming government strength, about 1,000 campesinos demanding "return of their land" rebelled in 1896. Following an

${ }^{70}$ Díaz Ramírez, Apuntes Históricos, 73.

${ }^{71}$ Tiburcio Montiel, "Comunismo," El Socialista, Number 28, July 31, 1878.

72 Díaz Soto y Gama, La Revolución Agraria, 43.

73 Montiel, "Comunismo," El Socialista, Number 28, July 31, 1878.

${ }^{74}$ Rafael Ramos Pedrueza, La Lucba de Clases a Través de la Historia de México, (México D. F., 1941), 412.

${ }^{75}$ Díaz Ramírez, Apuntes Históricos, 73. 
open battle with the federal army in which they were defeated, the indigenous rebels resorted to a vicious guerrilla war that continued until 1906 before they were finally wiped out. ${ }^{76}$ The Díaz regime reigned supreme; yet the agrarians, pushed by a relentless population growth and ever expanding hacienda system, had already developed that collection of ideas and attitudes that is known as agrarian ideology. ${ }^{77}$ Don Porfirio and his cientificos, with all the power that they possessed, were never able to undo the revolution that had occurred in the minds of the campesino population.

Despite claims that the Zapatista Plan de Ayala and Agrarian Law were "original," it is clear that the agrarian ideology developed in the nineteenth century, especially in Zapata's own area of operations, foreshadowed most of the concepts that would appear during the agrarian struggle of $1910 .{ }^{78}$ The Zapatista program included features of the precursors' proposals such as redistribution of land, conditions of compensation, municipio autonomy, municipio authority over actual land seizures and the awarding of communal or individual plots according to local tradition, the formation of a regional agricultural bank, and the guaranteed provision of basic farming implements such as seed, plows and oxen. ${ }^{70}$ The Plan de Ayala, as a revolutionary document, was more elaborate than its nineteenth-century predecessors; but, after all, it was the end product of an agrarian movement with a long history. As Professor John Womack states, "The plan (de Ayala) was not an instant creation. As a statement of attitudes it had been evolving for at least fifty years, through the public lessons Juárez had given in the supreme importance of 'principles,' 'law,' and 'justice,' through the formation of national pride in the resistance against the French, through the exasperation with personal promises and political abuses during Don Porfirio's long reign, and lately through the abortion of hopes in the

${ }^{78}$ Moíses González Navarro, El Porfiriato, Vida Social, Daniel Cosio Villegas, ed., La Historia Moderna de México (6 Volumes), Tomo 4, (México D. F., n. d.), 244.

${ }^{77}$ For data on land distribution and the size of haciendas before the Revolution of 17910 see Womack, Zapata, 391-392; Gildardo Magana, Emiliano Zapata y El Agrarismo en México (5 Volumes), Tomo 1, (México D. F., 1951), 39; and Domingo Diez, Dos Conferencias sobre el Estado de Morelos, (México D. F., 1919), 56.

78 Professor John Womack in his perceptive Zapata and the Mexican Revolution, 405, makes the claim of "originality" for Zapata's Plan de Ayala and Agrarian Law. Díaz Soto y Gama, however, has argued the case for the precursors with the claim that the Plan of Ayala offered the people nothing more than what the nineteenth century agrarians had proposed in the face of insurmountable odds (La Revolución Agraria, 49-50).

79 For the closest comparison see the "Ley del Pueblo," El Socialista, Number 30, August 4, 1878; and La Revolución Social, Number 2, December 18, 1879. 
virtuous Madero." ${ }^{80}$ There were, however, other important elements in this evolutionary process. Leaders such as Chávez López, Rhodakanaty, Zalacosta, González, Santa Fe, Montiel, and Negrete, in their own indefatigable way, made significant contributions to agrarian ideology in their struggles during the darkest days of the nineteenth century. An examination of their ideas contributes an added dimension to the history of the Mexican agrarian revolution.

University of North Dakota

Grand Forks, North Dakota

John M. HaRT

${ }^{80}$ Womack, Zapata, 393. 